\title{
Thomas Fleming Worlds Apart: British Columbia Schools, Politics, and Labour Relations Before and After 1972
}

Mill Bay, B.C.: Bendall Books 2011. 155 pp.

\author{
Ken Osborne \\ University of Manitoba
}

This book aims to "prompt a much-needed debate about the organizational and political conflicts that have disrupted British Columbia's schools for some time and that continue to imperil public education" (11). It primarily addresses two organizational issues. The first is the ability of the provincial school system, as currently organized, to handle the challenges it faces. The second is the relationship that exists among the organizations responsible for public education in B.C., particularly between the provincial government and the B.C. Teachers Federation. The book also raises, if only indirectly, some interesting questions about the role of history in the determination of public policy. Drawing heavily on historical data, Thomas Fleming, Professor Emeritus of Education at the University of Victoria, suggests that the B.C. Ministry of Education ignores its history, while its main antagonist, the B.C. Teachers Federation, is too much the prisoner of its past. As a result, "For the first time in its history public schooling stands without a story to tell and without bold new ideas to move it forward"(128).

Fleming divides the educational history of B.C into two parts. The first, lasting from 1872 to 1972 , was "a century of triumph" (23ff) when a handful of enlightened civil servants, aided by dedicated teachers and inspectors and supported by a cooperative public, created a school system that was "admired, envied in fact, by other jurisdictions across the nation" (37). After 1972, however, this "once harmonious school community was riven by politics, special interests, conflict, and organizational distrust" (12). For Fleming, the causes of this disintegration include the "shortsightedness" of school boards; the "confusion and lack of purpose" of the Ministry of Education; the retreat of university faculties of education into an "isolation ward of unintelligibility"; and above all the "puffery, self-righteousness, and blind ambition" 
of the BCTF (13-14). Left unexplored is the apparent paradox that, despite the turmoil, the quality of teaching in B.C. schools seems to have steadily improved. Indeed, today B.C. students do relatively well on national and international tests of achievement.

Apart from the fact that it marks the first time the BCTF directly intervened in a provincial election, it is not altogether clear why Fleming chooses 1972 as his dividing line. The BCTF affiliated with the Trades and Labour Congress from 1943 to 1956 and teachers struck in Vancouver and New Westminster in 1919 and 1921, so political action was hardly a new phenomenon. Moreover, Fleming himself makes a good case for taking the 1945 Cameron Report on school consolidation as a major turning point in B.C.'s educational history, showing that, while consolidation resulted in greater equity, it also relocated power from the province to local school boards, each with its own burgeoning bureaucracy, while also enlarging the bargaining power of the BCTF. The unanticipated result was the dissolution of the "cooperative and harmonious relationship that characterized the educational community before 1946" (60).

Though Fleming acknowledges the deficiencies of the pre-1972 school system, one wonders if its first century was quite the golden age that he portrays. The creation of the provincial school system was certainly an impressive achievement but a greater emphasis on what happened in the classroom might have produced a less up-beat picture. Provincial school inspectors were supportive of teachers but often voiced concern over what they saw as low standards of teaching, especially in the many small rural schools that dotted the B.C. landscape. To take only one subject, the century of triumph was dotted by a stream of national reports deploring the state of history education in Canadian, including British Columbian, schools. Fleming makes no mention of the B.C. Ministry of Education's 1920 banning of a respected history textbook in deference to complaints that it was insufficiently patriotic and despite the protests of history teachers and UBC historians. One wonders just what lay behind the lament of the provincial Superintendent of Education that, despite the book's merits, he was unwilling to engage in any more "official scraps having had in my lifetime a plethora of those nerve-destroying experiences" [C. Humphries, $B C$ Studies 1(1968-69): 11].

Fleming describes the B.C. government's acceptance of school boards' demands for increased resources in the 1970s as the "first time in provincial history that an education bureau had allowed individuals and organizations outside government to determine what schools would actually do" (63). The 1920 textbook incident suggests otherwise. Nor does he mention such episodes as the Victoria school strike organized by Chinese-Canadian students and parents in 1922-23, the recurrent debates over the schooling of Chinese-Canadian students, or various other controversies that flared up over the years.

Having surveyed the administrative history of the B.C. school system, Fleming devotes his third and final chapter to "stocktaking." True to his intention of provoking public debate, he does not provide an agenda for reform but instead offers a list of questions that he sees as needing to be addressed. Nonetheless, some of his 
preferences are clear: the consolidation, and perhaps even the elimination, of school boards; greater central control; more emphasis on the assessment of students' performance; and, above all, restraining what he sees as the destructive militancy of the BCTF. Regrettably, he does not provide a guide to the relevant research on these and related topics that citizens need if public debate is to be properly informed.

Fleming writes that "Disagreement about the past invariably precludes a shared vision of the future - and the cooperation it requires" (127). Perhaps so, though experience suggests that disagreement about the past does not necessarily preclude joint action in the present and there are obvious dangers in using the past to create a vision for the future. What history gives us is some understanding of how things come to be the way they are and perhaps a realization that they do not necessarily have to be that way. Nonetheless, Fleming raises questions that should be of interest to anyone with an interest in public education, not only in British Columbia but anywhere in Canada. 